\title{
Distance Learning Innovation Strategy in Indonesia During the COVID-19 Pandemic
}

\author{
Sylvi Marini ${ }^{1}$, Milawati Milawati ${ }^{2 *}$ \\ ${ }^{I}$ SMA Negeri 13 Samarinda \\ ${ }^{2}$ IKIP PGRI Kalimantan Timur \\ ${ }^{*}$ Corresponding author.Email: milawati@ikippgrikaltim.ac.id
}

\begin{abstract}
The outbreak of Coronavirus Disease (COVID-19) has resulted in face-to-face learning not being implemented properly. To reduce the spread of COVID-19, schools in Indonesia are conducting distance learning. This study aims to analyze the innovation strategies that have been implemented in distance learning in Indonesia during the COVID19 pandemic. The strategy is intended to create more advanced technology-based learning to adapt to the COVID-19 pandemic era and the era of education 4.0. COVID-19 provides an acceleration of digital transformation towards the education 4.0.
\end{abstract}

Keywords: COVID-19, distance learning, innovation

\section{INTRODUCTION}

The outbreak of Coronavirus Disease (Covid-19) has resulted in face-to-face learning not being implemented properly. To reduce the spread of Covid-19, most schools in Indonesia are carrying out distance learning. Distance learning during the Covid-19 pandemic in Indonesia provides great potential opportunities for teachers, school principals, and students to carry out various kinds of hybrid models or school learning management systems. In this case, all schools and parents adapt and experiment using technology for learning activities.

The Indonesian Ministry of Education and Culture encourages the implementation of the learning process to be carried out online. This is following the Circular of the Minister of Education and Culture of the Republic of Indonesia number 3 of 2020 concerning the Prevention of Corona Virus Disease (COVID-19) in the Education Unit, and the Letter of the Secretary-General of the Minister of Education and Culture number 35492 / A.A5 / HK / 2020 dated 12 March 2020 regarding the Prevention of the Spread of Corona Virus Disease (Covid-19).

Information technology is a solution to the implementation of distance learning. Many information media are used by educators to conduct distance learning, namely online learning $[9,21]$. This is certainly an indication of positive developments for the digital transformation of education in Indonesia. Education 4.0 can be seen as a creative response where humans take advantage of digital technology, open-source contents, and global classrooms in the application of lifelong learning, flexible education systems, and personalized learning, to play a better role in society. On the other hand, e-learning learning is not an answer to a question, but an adaptation of a condition that everyone is "forced" to do [4].

The teaching staff of all backgrounds and ages must prepare and deliver their classes from home, with all the practical and technical challenges it presents, and often without proper technical support [15]. The condition of the Covid-19 pandemic has resulted in extraordinary changes as if all levels of education are "forced" to transform to adapt suddenly to undertake distance learning. This is certainly not an easy thing, because it is not fully prepared. This is a tough challenge for teachers, lecturers, and parents. Not a few parents who work from home (WFH), must continue to accompany their children, especially those at an early age. This is because technology has not been introduced in the utilization of learning media such as laptops, gadgets, and others [23]. Even so, positive, creative, and innovative thinking can help implement distance learning during the Covid-19 pandemic to produce quality learning outcomes. 
Based on the description above, the purpose of this study is to analyze the innovation strategies that have been implemented by educators in Indonesia.

\section{THEORETICAL FRAMEWORK}

\subsection{Distance Learning}

Distance education is a set of teaching methods where teaching activities are carried out separately from learning activities. The separation of the two activities can be in the form of physical distance, for example, because the learning participants live far from the location of the educational institution [24].

Distance learning as a model of distance education is not a new educational model. At first, it started with written courses, then developed into a formal higher education in the form of an Open University. Among them, the University of Wisconsin in America has been a pioneer university in the world of distance education since 1891. In its development, nearly half of the approximately 3,900 higher education institutions in the United States provide some kind of distance education. The background of the holding of distance learning is that people who work every day with solid working time, live and work far from educational institutions will feel how much opportunity cost is lost if they have to attend conventional learning or lectures at these educational institutions because devoting a few hours each day to sitting in class, adjusting study schedules, practicum and all other activities to work hours. For this reason, various efforts have been made to support the realization of distance learning with better quality and service by utilizing developments in information and communication technology [25].

In the context of distance education, independent learners can learn in conditions that require them to learn without fully depending on the teacher [7].

\subsection{Learning Innovation Strategy}

The process of education from time to time continues to innovate, according to human development and capabilities, so that education has progressed quite rapidly. This is evidenced by the discovery of new science, which at the same time shows that education is always advanced and forward-oriented.

Innovation is a new change in the direction of improvement or different from what was before, done deliberately, and planned. In the context of learning technology, innovation refers to the use of advanced technology, both software, and hardware in the learning process. The main objective of the application of this new technology is to improve the quality, effectiveness, and efficiency of learning. Methods and strategies are also an innovation in learning [33].

To optimize learning delivery methods, there is a need to examine technology-mediated learning strategies [26]; Which means, how teaching can be improved through the use of technology. Web learning media (e.g., static and dynamic web pages, threaded discussion groups, email, chat, instant messaging, streaming / video media, animation, application sharing, IP audio/video conferencing) are being adopted and increasingly used by teachers to optimize the delivery of learning materials [27]. Web-based learning can be classified into one of three categories: Developed, dependent, or supported [26].

\subsection{COVID-19}

At the beginning of 2020, the world was shocked by the outbreak of a new virus, namely, a new type of Coronavirus (SARS-Cov-2), and the disease is called Coronavirus disease 2019 (COVID-19). The origin of the virus is known to have come from Wuhan, China in December 2019 [28]. Common signs and symptoms of COVID-19 infection include symptoms of acute respiratory disorders such as fever, cough, and shortness of breath. The average incubation period is 5-6 days with the longest incubation period of 14 days. On January 30,2020 , WHO has declared it a public health emergency that is troubling the world. On March 2, 2020, Indonesia reported 2 confirmed cases of COVID19. As of March 16, 2020, 10 people have tested positive for corona [16].

The lungs are the organs most attacked by this virus because the virus accesses the host cells through certain enzymes found in the alveolar type II cells of the lungs. [16]The main symptoms that are caused are fever, fatigue, dry cough and there are also other symptoms, such as nasal congestion, runny nose, pharyngula, myalgia, and diarrhea. It can even occur to something more severe such as acute respiratory distress syndrome, septic shock, bleeding dysfunction, coughing, and multiple organ failure. Older people are very vulnerable to a more severe stage because they carry other congenital diseases [31].

So dangerous is this disease, that the government is working hard to contain the spread of COVID-19. Until now, no cure or vaccine has been found for this problem, so the only way is to break the chain of the spread of COVID-19. The most effective way to break the chain of the spread of this outbreak is by carrying out social distancing and physical distancing [17]. Social restrictions are maintaining distance in socializing, maintaining distance in carrying out social activities, including limiting oneself to socializing in society, minimizing boxes with other individuals. Likewise, the physical restriction means restriction by keeping the body physically 1-2 meters away when making contact or in contact with other individuals. Besides that, a clean and healthy lifestyle is also very important to break the chain of spreading this virus, such as always using a mask, diligently washing hands, etc. [34].

\section{METHOD}

This type of research is library research, which is a series of studies relating to the method of collecting library data, or research where the object of research is explored through a variety of library information 
(books, encyclopedias, scientific journals, newspapers, magazines, and documents).

\section{RESULTAND DISCUSSION}

\subsection{The Potential and Challenge of Distance Learning During the COVID-19 Pandemic}

Shearer [30] states that distance learning contributes quantitatively to teaching and learning interactions. The interaction in face-to-face learning is limited, namely between the teacher and the learner, but in distance learning the learning interaction is more spread out. Interactions will occur between learners and learners, learners and teachers, learners with the environment, or learners with the media. According to Lindner, Murphy and Briers [20], this interaction occurs because of the support of tools, namely e-learning which includes static and dynamic web, discussion groups, e-mail, chatting, instant messaging, video streaming, animation, sharing applications, and video. conferencing. Online distance learning can enable learners, namely learners to actively interact to use computers, physical and mental activities will occur intensively, for example, dop and drag, data input, search for required data, compiling learning materials, and others.

The Covid-19 Pandemic seems to force the world of education to shift from a traditional learning system to a more modern learning system. The implementation of online learning requires teachers and students to have the skills to use devices such as laptops and smartphones in learning. They are also required to be skilled in selecting and using the information on the internet that is relevant to the material being discussed.

If all this time teachers have only relied on projectors and PowerPoint slides in teaching, during the Covid-19 Pandemic, teachers had to use other learning media that were following the context of online learning. Teachers must be able to use various Learning Management Systems (LMS) that can properly convey material to students, as well as design assessment methods that can measure student learning outcomes in an online learning environment. The implementation of online learning during the Covid-19 emergency changed the whole learning process. Unexpectedly, the implementation of online learning has a positive impact on student learning independence. The absence of physical teachers in learning limited communication between teachers and students. The teacher's explanation through virtual classes is considered insufficient so that students take the initiative to find and use other references to support their understanding of the material being taught. Asynchronous online learning carried out by the teacher encourages students to be more active in learning. [32] Online learning eliminates awkwardness which in turn makes students more courageous in expressing questions and expressing ideas freely.

The flexibility of online learning time allows students to organize their learning. In online learning, teachers usually upload material with assignments and set a deadline for submitting these assignments. This becomes a reference for students to independently plan time for study and time to do assignments. Kuo et al., [18] stated that online learning is more student-centered, which causes them to be able to take responsibility for learning.

On the one hand, the implementation of online learning is not without problems. Network problems, lack of training, and lack of awareness were cited as the main challenges faced by educators. Lack of awareness was cited as the most important reason by those who did not adopt online learning followed by a lack of interest and doubts about the usefulness of online learning. Lack of attendance, lack of personal touch, and lack of interaction due to connectivity issues were found to be significant drawbacks of online learning [3]. The obligation to study at home becomes a serious obstacle, especially for students from economically disadvantaged circles. They often complain about running out of internet quota packages. Also, technology is considered to be able to build an instant attitude for its users [29]. There is additional work for parents in assisting children in learning, communication and socialization between students, teachers, and parents is reduced and working hours are unlimited for teachers because they have to communicate and coordinate with parents, other teachers, and school principals.

Regarding the readiness of human resources. The condition of teachers in Indonesia does not fully understand the use of technology, this can be seen from teachers born before the 1980s. Information technology constraints limit their use of online media. The lack of readiness for the provision of budget funds is also an obstacle because the aspects of the welfare of teachers and students are still far from expectations. When they use their internet quota to meet their online media needs, they obviously can't afford it. There is a dilemma in the use of online media when the minister of education encourages productivity to move forward, but on the other hand, the financial skills and abilities of teachers and students have not moved in the same direction. The state has not yet been fully present in facilitating the cost requirements referred to [1].

According to Fajrussalam [11] the challenges in distance learning during the Covid-19 pandemic were the lack of motivation, honesty, and discipline of students because they felt they were not being supervised and there was freedom, so the learning process was not optimal. 


\subsection{Distance Learning Innovation Strategies During the COVID-19 Pandemic}

Creation to innovate, including innovation in the field of education. Education is a basic milestone in the development of a country, it is necessary to adapt and innovate technology to survive in the era of education 4.0.

If distance-learning is carried out properly and correctly, the results are quite encouraging and are not inferior to conventional face-to-face learning outcomes. In its implementation, several important factors must be considered, so that the distance education (learning) system can run well, namely attention, educator confidence, experience, easy use of equipment, creative use of tools, and establishing interactions with students. The effectiveness of distance learning on students' understanding of learning is one of the factors that consider the application of distance learning for longterm education. Indeed, it is not only the teaching factor and the learning system that are influential, but these two things also encourage other factors, namely the level of curiosity and also the independence of students.

According to Yuangga and Sunarsi [33], the problem of online distance learning in this pandemic is related to a large number of unpreparedness between students and teachers, this is because students must be able to understand the material by themselves without direct explanation from the teacher while the teacher must be able to convey the material effectively. Therefore, teachers must be creative and innovative to continue to be able to provide effective learning for students.

The learning strategy used during this pandemic was carried out by using several application choices, namely, WhatsApp, google meet application, zoom application, and using the google web classroom. The application was chosen because it can be used according to the needs of its users. WhatsApp can send text messages, voice and video messages, share various images, videos, document learning materials, and more. The google classroom application functions the same as WhatsApp but the application is commonly used for discussions and sending assignments to make it easier and tidier, while they meet and zoom applications are for face-toface online meetings so that teachers can see the faces of their students who pay attention to the teacher when providing material explanations.

Implementing internet-based learning does not mean simply putting teaching materials on the web. In addition to teaching materials, learning scenarios need to be carefully prepared to invite active and constructive involvement of students in their learning process [10]. Then an effective strategy must be made so that learning remains optimal. In this regard, it is necessary to examine the important role of testing one particular type of application before it is operationally implemented.

To use internet facilities, you need a cell phone or computer and the availability of an internet signal, but not all teachers and students have these facilities. Teachers and students who have no financial constraints and internet signals have many alternatives, but on the other hand, teachers, and students who have financial and / signal barriers will experience difficulties in carrying out the learning process. To overcome this problem, the government, in this case, the Ministry of Education and Culture, provides a solution by implementing learning services through TVRI media. TVRI media is not optimal because learning through TV only takes place in one direction and time is very limited. On the other hand, not all areas are covered by TV and many Indonesian citizens do not have a TV. Thus the government must continue to innovate to carry out the learning process effectively.

[5] Reveals several factors that can create interesting learning experiences for online learners. The main factors are as follows: creating and maintaining a positive learning environment; building learning communities; provide consistent feedback promptly; and using the right technology to deliver the right content. According to [22] As online learning opportunities increase in today's society, librarians need to consider additional ways to design online instruction effectively. Developing the strategies needed to teach and learn online successfully requires an understanding of learning styles and how they can best be handled in an online environment. As is the case in face-to-face classes, the use of a particular teaching style or set of styles should be extended to address different learning styles when teaching online. Successful teaching and learning depend on all participants having the attitudes necessary to succeed in an online environment.

\section{CONCLUSION}

Education is a basic milestone in the development of a country, it is necessary to adapt and innovate technology so that it can survive in the era of education 4.0. If it persists with the current way of learning, education in Indonesia will be left behind with other countries in the world.

Based on this, the online learning program needs to prepare supporting facilities, competencies, and prior training for students, teachers, and parents. Without good preparation, it will affect the quality of teaching and learning outcomes. During this pandemic, our education was forced to take advantage of digital technology, in other words, Covid-19 provided an acceleration of digital transformation towards the era of education 4.0 . 


\section{REFERENCES}

[1] Aji, R. H. S. Dampak Covid-19 pada Pendidikan di Indonesia: Sekolah, Keterampilan, dan Proses Pembelajaran. SALAM: Jurnal Sosial \& Budaya Syar'I, 2020,7(5), 395-402.

[2] Angeli, C., \& Valanides, N. Preservice elementary teachers as information and communication technology designers: an instructional systems design model based on an expanded view of pedagogical content knowledge. Journal of Computer Assisted Learning, 2005,21(4), 292-302.

[3] Arora, A. K., \& Srinivasan, R. Impact of pandemic COVID-19 on the teaching -learning process: A study of higher education teachers. Prabadhan: Indian Journal of Management, 2020, 13 (4).

[4] Astini, Ni Komang Suni. Tantangan Dan Peluang Pemanfaatan Teknologi Informasi Dalam Pembelajaran Online Masa Covid-19. Cetta: Jurnal Ilmu Pendidikan, 2020,3(2), 241-255.

[5] Chakraborty, M. and Muyia Nafukho, F. "Strengthening student engagement: what do students want in online courses?", European Journal of Training and Development, Vol. 38 No. 9, 2014, pp. 782-802.

[6] Ching, Y.-H., Hsu, Y.-C., \& Baldwin, S. Becoming an online teacher: an analysis of prospective online instructors' reflections. Journal of Interactive Learning Research, 2018, 29(2), 145-168.

[7] Darmayanti, Tri. Efektivitas intervensi keterampilan self-regulated learning dan keteladanan dalam meningkatkan kemampuan belajar mandiri dan prestasi belajar Mahasiswa Pendidikan Jarak Jauh: Jurnal Pendidikan Terbuka dan Jarak Jauh, 2008, 9( 2), 68-82.

[8] Dewi, W. A. F. Dampak covid-19 Terhadap Implementasi Pembelajaran Daring di Sekolah Dasar. Edukatif: Jurnal Ilmu Pendidikan, 2020, 2(1), 55-61.

[9] Durriyah, T.L \& Zuhdi, M. Digital Literacy With EFL Student Teachers: Exploring Indonesian Student Teachers' Initial Perception About Integrating Digital Technologies Into a Teaching Unit. International Journal of Education \& Literacy Studies, 2018,6(3), 53-60.

[10] Elyas, A. H. Penggunaan Model Pembelajaran ELearning Dalam Meningkatkan Kualitas Pembelajaran. Jurnal Warta Edisi: 56. Universitas Dharmawangsa. 2018.

[11] Fajrussalam, H., dkk. Inovasi Pesantren Ramadhan dalam Meningkatkan Kecerdasan Spiritual Peserta
Didik di Masa Pandemi Covid-19. EduTeach: Jurnal Edukasi dan Teknologi Pembelajaran, 2020, $1(2), 1-10$

[12] Firman. Dampak Covid-19 terhadap Pembelajaran di Perguruan Tinggi. BIOMA, 2020,2(1), 14-20.

[13] Goodyear, P. Teaching online. In N. Hativa \& P. Goodyear (Eds.), Teacher thinking, beliefs and knowledge in higher education, 2002,. (pp. 79101). Dordrecht: Kluwer Academic Publishers.

[14] Hiatt, J. ADKAR: A model for change in business, government and our community. Loveland, Colorado, USA: Prosci Learning Center Publications, 2006.

[15] Hodges, C., Moore, S., Lockee, B., Trust, T., \& Bond, A. The difference between emergency remote teaching and online learning. Educause Review, 27 March, 2020.

[16] Kementerian Kesehatan Republik Indonesia. Pedoman Pencegahan dan Pengendalian Coronavirus Disease (COViD-19) Revisi Ke-4. Jakarta: Direktorat Jenderal Pencegahan dan Pengendalian Penyakit, 2020.

[17] Kementerian Pendidikan dan Kebudayaan Republik Indonesia. Surat Edaran Nomor 4 tahun 2020 Tentang Pelaksanaan Pendidikan dalam Masa Darurat Covid-19. Retrive from https://kemdikbud.go.id/main/blog/2020/03/mendi kbud-terbitkan-se-tentang-pelaksanaan-pendidikandalam-masa-darurat-covid-19, 30 august, 2020.

[18] Kuo, Y. C., Walker, A. E., Schroder, K. E. E., \& Belland, B. R. Interaction, Internet self-efficacy, and self-regulated learning as predictors of student satisfaction in online education courses. Internet and Higher Education, 2014.

[19] Lewis, S., Whiteside, A. and Dikkers, A, "Providing Chances for Students to Recover Credit: Is Online Learning a Solution?", Exploring Pedagogies for Diverse Learners Online (Advances in Research on Teaching, Vol. 25), Emerald Group Publishing Limited, 2015,pp. 143-157.

[20] Lindner, Jr., Murphy, T.H., \& Briers, G.H. Handling nonresponse in sosial science research. Journal of Agricultural Education, 2001,42(4), 4353.

[21] Manca, S. \& Ranierit, M. Is it a tool suitable for learning? A critical review of the literature on Facebook as a technology-enhanced learning environment. Journal of Computer Assited Learning, 2013, 29, 487-504. 
[22] Miarso, Y. Menyemai Benih Teknologi Pendidikan. Jakarta: Rajawali, 2004.

[23] Moore, M. G. Toward a theory of independent learning and teaching. Journal of Higher Education, 1973, 44(9), 661-679.

[24] Munir. Pembelajaran Jarak Jauh Berbasis Teknologi Informasi dan Komunikasi, 2009. Bandung: Alfabeta.

[25] Siregar, E., Rajagukguk, J., \& Sinulingga, K. Improvement of Science Process Skills Using Scientific Inquiry Models With Algodoo Media and Quotient Adversity in High School Students. Journal of Transformative Education and Educational Leadership, 2020, 1(2), 53-65.

[26] Olliges, R., Wernet, S. P., \& Delicath, T. A. Using WebCT to educate practice professionals. Proceedings of the Dancing Web Conference, Columbus, Ohio, 1999.

[27] Perhimpunan Dokter Paru Indonesia. Panduan Praktik Klinis: Pneumonia 2019-nCov, 2020. PDPI: Jakarta.

[28] Purwanto, A., Pramono, R., Asbari, M., Budi Santoso, P., Mayesti Wijayanti, L., Chi Hyun, C., \& Setyowati Putri, R. Studi eksploratif dampak pandemi COVID-19 terhadap proses pembelajaran online di sekolah dasar. Journal of Education, Psychologi and Counseling, 2020, 2(1), 1-12.

[29] Saxena, S. K. Coronavirus Diseas 2019 (COVID19): Epidemoogy, Pathogenis, Diagnosis, and Therapeutics, 2020. Singapore. Springer Pte Ltd.

[30] Shearer, R. Instructional Design in Distance Education: An Overview. In. M. G. Moore \& W. G. Anderson (Editors). Handbook of Distance Education, 2003. Pp 275-286. Mahwah, New Jersey: Lawrence Erlbaum Associates, Publisher.

[31] Sun, P. C., Tsai, R. J., Finger, G., Chen, Y. Y., \& Yeh, D. What drives a successful eLearning? An empirical investigation of the critical factors influencing learner satisfaction. Computers and Education, 2008.

[32] Warsita, Bambang. Teknologi Pembelajaran, Landasan dan Aplikasinya. Jakarta: Rineka Cipta, 2008.

[33] Yuangga, K.D \& Sunarsi, D. Pengembangan Media dan Strategi Pembelajaran Untuk Mengatasi Permasalahan Pembelajaran Jarak Jauh di Pandemi Covid-19. Guru Kita, 2020, 4(3), 51-58.

[34] Zhou, W. Buku panduan pencegahan coronavirus: 101 tips berbasis sains yang dapat menyelamatkan hidup anda. Fin e-book. https://fin.co.id, 2020 